\title{
Anti-Apoptotic Role of Sanhuang Xiexin Decoction and Anisodamine in Endotoxemia
}

\author{
Zixuan Liu ${ }^{1,2 \dagger}$, Wenxiang Wang ${ }^{1,2 \dagger}$, Jie Luo ${ }^{1,2}$, Yingrui Zhang ${ }^{1,2}$, Yunsen Zhang ${ }^{2}$, \\ Zhiqiang Gan $^{1,2}$, Xiaofei Shen ${ }^{3}$, Yi Zhang ${ }^{1,2 *}$ and Xianli Meng ${ }^{4 *}$
}

${ }^{1}$ Ethnic Medicine Academic Heritage Innovation Research Center, Chengdu University of Traditional Chinese Medicine, Chengdu, China, ${ }^{2}$ School of Ethnic Medicine, Chengdu University of Traditional Chinese Medicine, Chengdu, China, ${ }^{3} T C M$ Regulating Metabolic Diseases Key Laboratory of Sichuan Province, Hospital of Chengdu University of Traditional Chinese Medicine, Chengdu, China, ${ }^{4}$ Innovative Institutes of Chinese Medicine and Pharmacy, Chengdu University of Traditional Chinese Medicine, Chengdu, China

Endotoxemia is characterized by initial uncontrollable inflammation, terminal immune paralysis, significant cell apoptosis and tissue injury, which can aggravate or induce multiple diseases

\section{OPEN ACCESS}

Edited by:

Hong Zhang,

Shanghai University of Traditional Chinese Medicine, China

Reviewed by:

Jwu-Lai Yeh

Kaohsiung Medical University, Taiwan Ina Yosifova Aneva,

Bulgarian Academy of Sciences, Bulgaria

*Correspondence: Yi Zhang zhangyi@cdutcm.edu.cn Xianli Meng

xlm999@cdutcm.edu.cn

${ }^{+}$These authors have contributed equally to this work

Specialty section:

This article was submitted to Ethnopharmacology,

a section of the journal

Frontiers in Pharmacology

Received: 20 February 2020

Accepted: 24 March 2021

Published: 21 April 2021

Citation:

Liu Z, Wang W, Luo J, Zhang Y, Zhang $Y$, Gan Z, Shen $X$, Zhang $Y$ and Meng $X$ (2021) Anti-Apoptotic Role of

Sanhuang Xiexin Decoction and Anisodamine in Endotoxemia. Front. Pharmacol. 12:531325. doi: $10.3389 /$ fphar.2021.531325 and become one of the complications of many diseases. Therefore, anti-inflammatory and anti-apoptotic therapy is a valuable strategy for the treatment of endotoxemia-induced tissue injury. Traditional Chinese medicine exhibits great advantages in the treatment of endotoxemia. In this review, we have analyzed and summarized the active ingredients and their metabolites of Sanhuang Xiexin Decoction, a famous formula in endotoxemia therapy. We then have summarized the mechanisms of Sanhuang Xiexin Decoction against endotoxemia and its mediated tissue injury. Furthermore, silico strategy was used to evaluate the anti-apoptotic mechanism of anisodamine, a well-known natural product that widely used to improve survival in patients with septic shock. Finally, we also have summarized other anti-apoptotic natural products as well as their therapeutic effects on endotoxemia and its mediated tissue injury.

Keywords: endotoxemia, anti-apoptosis, immunosuppression, herbal medicine, sanhuang xiexin decoction, anisodamine

\section{INTRODUCTION}

Possible sources of plasma endotoxin are bacteria from infected local tissues, blood, respiratory tract, digestive tract, food, or other ingested matter (Munford, 2016). The intestinal and other epithelial cells, such as those of the skin or lungs, are the first line of defense against endotoxins entering the bloodstream. Bacteria release bacterial lipopolysaccharide (LPS) or endotoxins mainly through lymphatic channels (e.g., small intestinal lymphatic system) and thoracic duct into the circulation from infected parts. Furthermore,

Abbreviations APAF1, Apoptotic protease activating factor-1; BAK1, B-Cell leukemia-2 antagonist killer-1; BAX, Bcl2 associated X-protein; Bcl2, B-Cell leukemia-2; BID, BH3 interacting death domain; BIM, B-Cell leukemia-2 interacting protein; CLSM, Confocal laser scanning microscopy; ECP, Eos cationic protein; EDN, Eos-derived neurotoxin; ETX, endotoxin; FADD, Fas-associated via death domain; FasL, Fas ligand; FM, Fluorescence microscopy; ICAD, Inhibitor of caspase-activated dNase; INOS, inducible nitric oxide synthase; LPS, lipopolysaccharide; MBP, Major base proteins of eosinophils; MODS, organ dysfunction syndrome; MOMP, Mitochondrial outer membrane permeabilization; NO, nitric oxide; OM, Optical microscopy; PTEN, phosphatase and tensin homolog deleted on chromosome-10; PUMA, p53-upregulated modulator of apoptosis; p53AIP1, p53-regulated apoptosis-inducing protein-1; RIP, Receptor-interacting protein; ROS, reactive oxygen species; SIRS, systemic inflammatory response syndrome; TNFR1, TNF receptor 1; TLM, Transmission electron microscopy; TRADD, Tumor necrosis factor receptor-1-associated death domain 


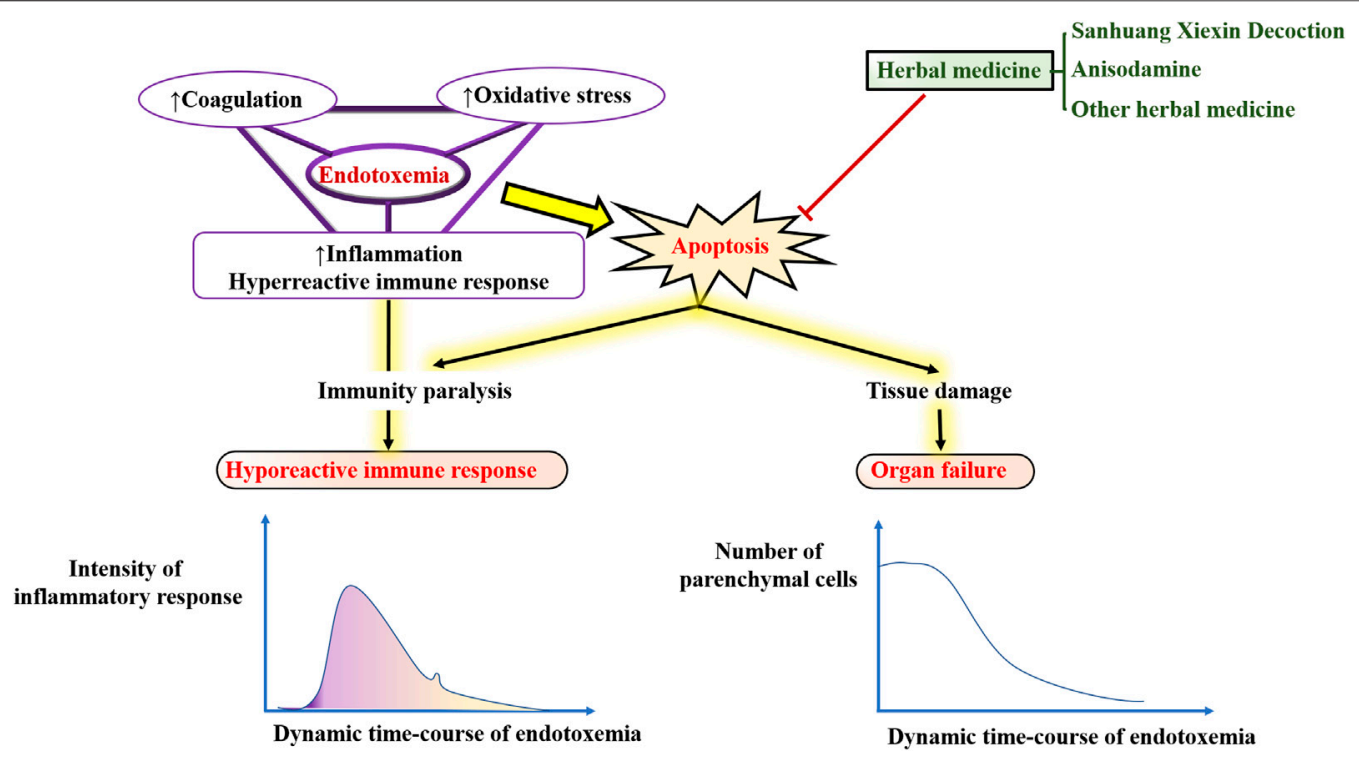

GRAPHICAL ABSTRACT |

LPS can also be absorbed from the gastrointestinal mucosa, especially the damaged intestinal mucosa (Brenchley, 2006) into the portal circulation. Erridge (Erridge, 2011) and Deitch (Deitch, 2012) showed that the largest source of LPS detected in the peripheral venous blood was from the small intestine. In addition, blood-borne bacteria can release LPS directly into the bloodstream to cause diseases, such as $N$. meningitidis (Ovstebo et al., 2005; Coureuil et al., 2014) and E. coli (Simpson et al., 2000). However, when the amount of endotoxin is overloaded, the host defense fails to eliminate and control the infection, leading to endotoxemia or even sepsis (Piwowar, 2014). In addition to endotoxemia/sepsis, excessive amounts of LPS are also implicated in the pathogenesis of a range of diseases, such as atherosclerosis, alcoholic liver disease, autoimmunity, metabolic syndrome, renal injury, multiple organ failure, depression, and chronic fatigue. Interestingly, these diseases both share a common pathophysiological basis: the imbalance between induction of apoptosis and resistance to apoptosis (Manco et al., 2010).

Apoptosis is a conserved process of programmed cell death characterized by chromatin fragmentation and condensation, membrane blebbing, and nuclear collapse. Apoptosis also plays important roles in a variety of physiological processes, including embryogenesis, tissue remodeling, immune response, and carcinogenesis (Kerr et al., 1972; Williams, 1991). In this process, cells that are no longer needed or that will be detrimental to an organism or tissue are disposed of in a highly ordered manner. This process can effectively block the development of inflammatory responses and tumorigenesis. Figure 1 illustrates how endotoxemia occurs, with six apoptosis hallmarks and related assays to distinguish apoptosis cells from normal healthy ones.

It has been shown that various herbal ingredients exhibit potent anti-apoptotic effects and improve the survival rate in experimental endotoxemia models. In the last decade, an increasing number of studies have emphasized that the reduced incidence of various endotoxin-related pathologies is closely related to herbal medicine, which is a good source of beneficial natural anti-inflammatory, anti-oxidative stress, and anti-coagulant bioactive compounds. Moreover, the active ingredients of many herbs have been used to treat endotoxemia and its complications with impressive efficacy. For example, the administration of anisodamine significantly improved the survival rate of septic shock. Considering the complexity of the apoptosis-related endotoxemia mechanisms and the fact that the modulatory effects of herbs are difficult to be systematically presented in various experimental studies. Therefore, we wrote this review to provide a general and descriptive overview of the potential role and underlying mechanisms of apoptosis-related progression in endotoxemia, as well as biomarkers and assays for endotoxemia, and the bidirectional regulation of apoptosis in endotoxemia by herbal components and their metabolism (especially Sanhuang Xiexin decoction and Anisodamine).

This review explores these issues by taking a novel perspective on apoptosis regulation in the treatment of endotoxemia. It begins with the herbal ingredients that may affect the inflammatory response, visceral protection, and apoptosis of endotoxemia in vitro and in vivo. How the major herbal ingredients are metabolized will then be discussed, followed by a summary of these metabolites and their effects. The review concludes by considering the influencing factors that determine whether herbal ingredients regulating apoptosis are advantageous in therapeutic endotoxemia.

\section{ENDOTOXEMIA IS ASSOCIATED WITH VARIOUS DISEASES}

Numerous variables can be activated in endotoxemia, including circulating glucocorticoid, cytotoxic T lymphocytes, oxygen free 


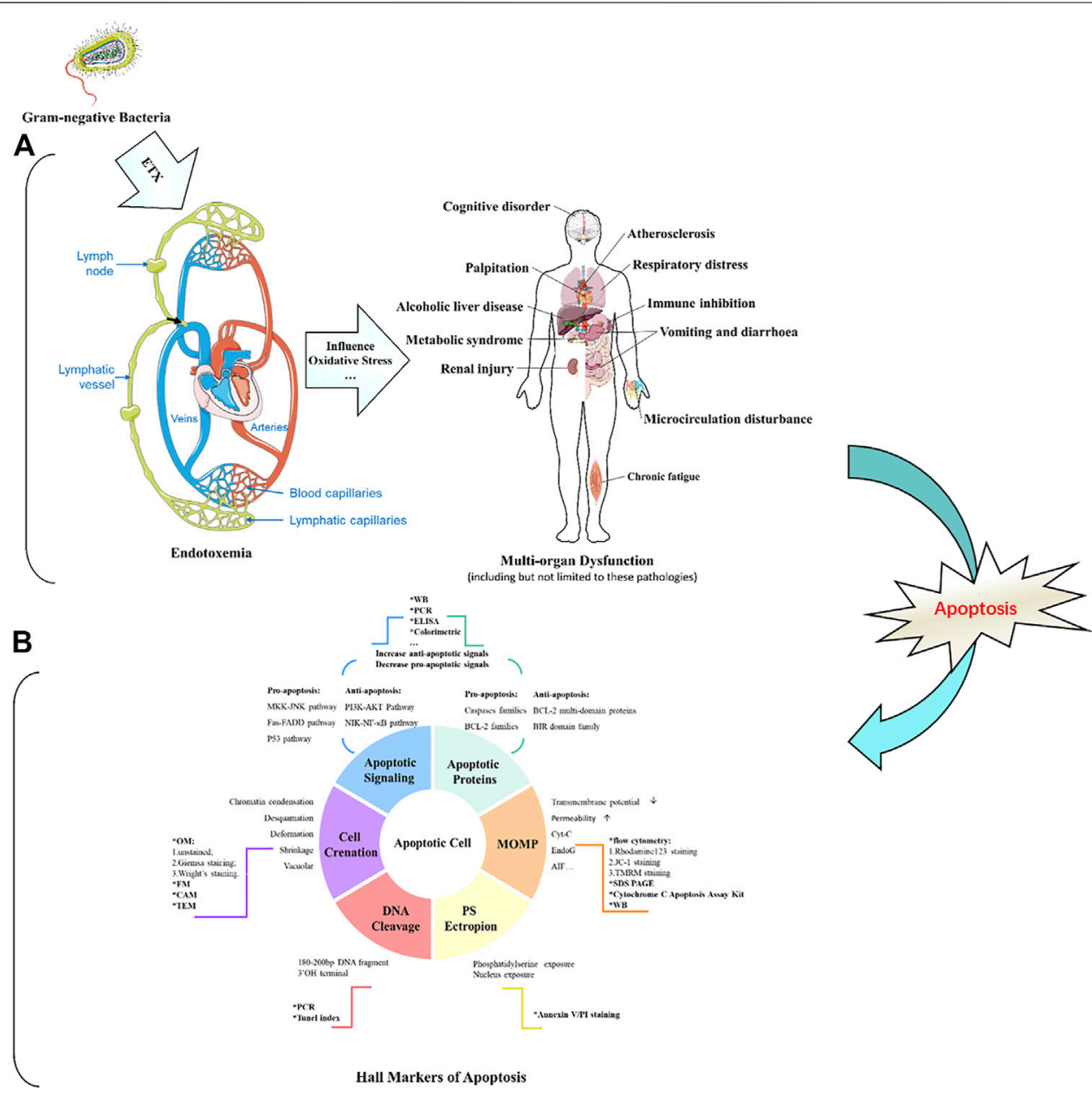

FIGURE 1 | Schematic diagram of endotoxin damage and the detection of apoptotic cells.

radicals, nitric oxide, heat shock proteins, FAS ligand, and proinflammatory cytokines (e.g., TNF-a, IL-1, and IL-6); all of these factors may initiate apoptosis (Harjai et al., 2013). Recently, regulation of the apoptotic process has been considered as a new therapeutic strategy for the treatment of endotoxemia and its complications (Eduardo and Fresno, 2013). Therefore, an indepth understanding of the molecular regulation of endotoxininduced apoptosis could provide a scientific basis for the intervention and treatment of the various diseases mentioned in Figure 1.

\section{ETX INDUCES APOPTOSIS IN VITRO AND IN VIVO}

ETX receptors could be divided into the following categories: scavenger receptor (SR), lipopolysaccharide-binding protein (LBP), cluster of differentiation antigen 14 (CD14) (Ulevitch and Tobias, 1995), $\beta 2$-integrins (such as CD11/CD18), and Toll-like receptors (TLRs). They are extensively distributed on the surface of immune cells such as monocytes, macrophages, and neutrophils and play an important role in the recognition and elimination of ETX in the host. The binding of LPS to LBP activates transmembrane receptors such as SR, $\beta 2$-integrins, and TLRs to transmit signals into the cell. These signals further promote the activation of transcription factors and induce the expression of pro-inflammatory genes. The expression of these overproduced pro-inflammatory products can further cause the induction of apoptosis. Apoptosis is induced by the intrinsic (mitochondrial) pathway and the extrinsic (death receptormediated) pathway (Danial and Korsmeyer, 2004). The intrinsic pathway involves mitochondria and depends mainly on Bcl2 family proteins and caspase 9/7/6/3 (Hengartner, 2000; Leist and Jäättelä, 2001). The extrinsic pathway is involved in death signaling, such as TNF- $\alpha$ with TNF receptor 1 (TNFR1). Then, the activation of death signaling further activates caspase- 8 , which cleaves procaspase- 3 into its active form and activates various genes such as P53, Fas, Bcl2, and NF$\kappa \mathrm{B}$ alone (Micheau and Jürg, 2003; Peter and Krammer, 2003). In contrast, the NF- $\kappa \mathrm{B}$ signaling cascade and $\mathrm{p} 53$ activate proapoptotic $\mathrm{Bcl} 2$ family proteins and inhibit anti-apoptotic $\mathrm{Bcl} 2$ family proteins and inhibitors of apoptotic proteins (cIAPs) via 
transcription, as well as several other p53 targets such as BAX, Noxa (Latin for damage, a $\mathrm{BH} 3$ protein involved only in regulating cell death decisions), p53-upregulated apoptosis regulator (PUMA) and BID to trigger apoptosis. Furthermore, p53 also transactivates several other genes that may contribute to apoptosis, including phosphatase and tensin homolog deleted on chromosome-10 (PTEN), APAF1, Perp, and genes that cause elevated levels of reactive oxygen species (ROS). The overproduction of ROS leads to extensive oxidative damage to all components of mitochondria. Mitochondrial DNA damage induced by ROS further disrupts the oxidative phosphorylation of mitochondria, which leads to a range of human diseases. Herbal ingredients are often involved in the treatment of endotoxemia with anti-inflammatory, antioxidant, and anti-apoptosis effects, which are interrelated and affect each other. Interestingly, however, there is no one-to-one correlation between anti-inflammatory/antioxidant and antiapoptotic/pro-apoptotic.

Endotoxin has been reported to significantly induce apoptosis in vitro and in vivo (O'Brien and Abraham, 2004; Neff et al., 2006; Li et al., 2018). ETX can directly stimulate the production of cytokines by monocytes-macrophages to activate the body's local or overall immune system against bacterial infections. On the other hand, if the infection is severe, large amounts of ETX in the body come into contact with mononuclear-macrophages and release vast inflammatory cytokines such as TNF-a leading to an uncontrolled inflammatory response. In addition, ETX stimulates the production of large amounts of nitric oxide (NO) by inducing non-calcium-dependent inducible nitric oxide synthase (INOS) in vascular cells. ETX also activates monocytes, macrophages, and neutrophils, and further promotes the expression of apoptosis-related receptors, such as Fas, TLR-2, and CD14, which can also induce apoptosis and tissue damage (Hotchkiss et al., 2002). Apoptosis of parenchymal cells can lead to dysfunction in multiple organs, while apoptosis of immune cells manifests as impaired host immune tolerance and immunosuppression (Hotchkiss et al., 2005), ultimately leading to septic shock, systemic inflammatory response syndrome (SIRS), organ dysfunction syndrome (MODS), and death. Interestingly, in sepsis, both pro- and anti-apoptotic members of the apoptosis-related pathway are upregulated, but the ratio is more favorable to the pro-apoptosis. In addition, lymphocytes are susceptible to endotoxin-induced apoptosis, with increased apoptosis of $\mathrm{CD}^{+} \mathrm{T}$ cells (Jäättelä and Tschopp, 2003), B cells, and follicular dendritic cells in the spleen of patients, while oxidative stress can lead to apoptosis of thymocytes (Fehsel et al., 1995). Although there is evidence that granulocytes can limit inflammatory damage through apoptosis, this is macrophage-dependent because the phagocytosis of apoptotic cells by macrophages effectively prevents the release of toxic content from dead cells. If a large number of macrophages undergo apoptosis, the apoptotic granulocytes will eventually lyse and release toxic molecules such as elastase and myeloperoxidase from neutrophils, major
A
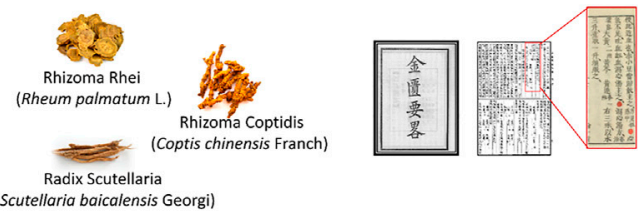

(Scutellaria baicalensis Georgi)

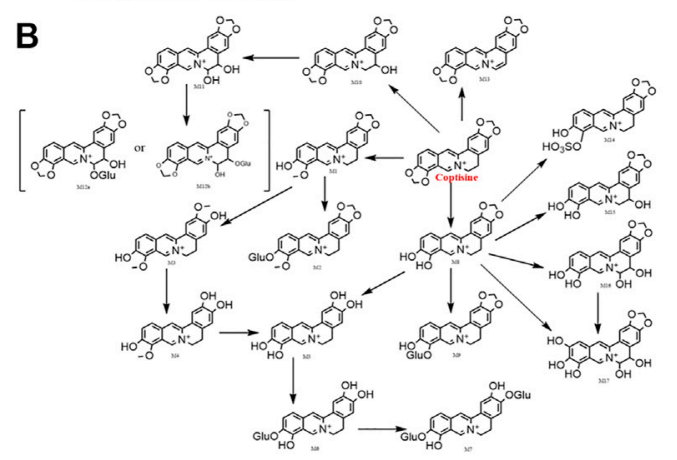

C
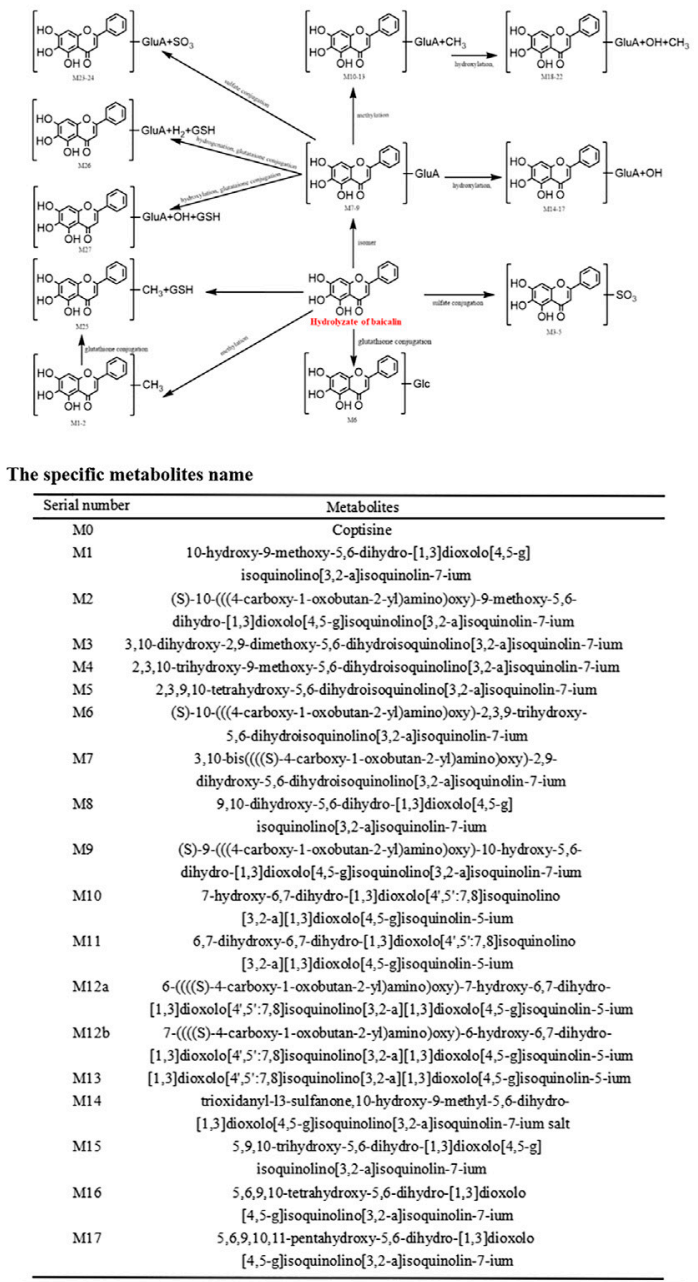

FIGURE 2 | Metabolic pathways of main components of Sanhuang Xiexin Decoction. 


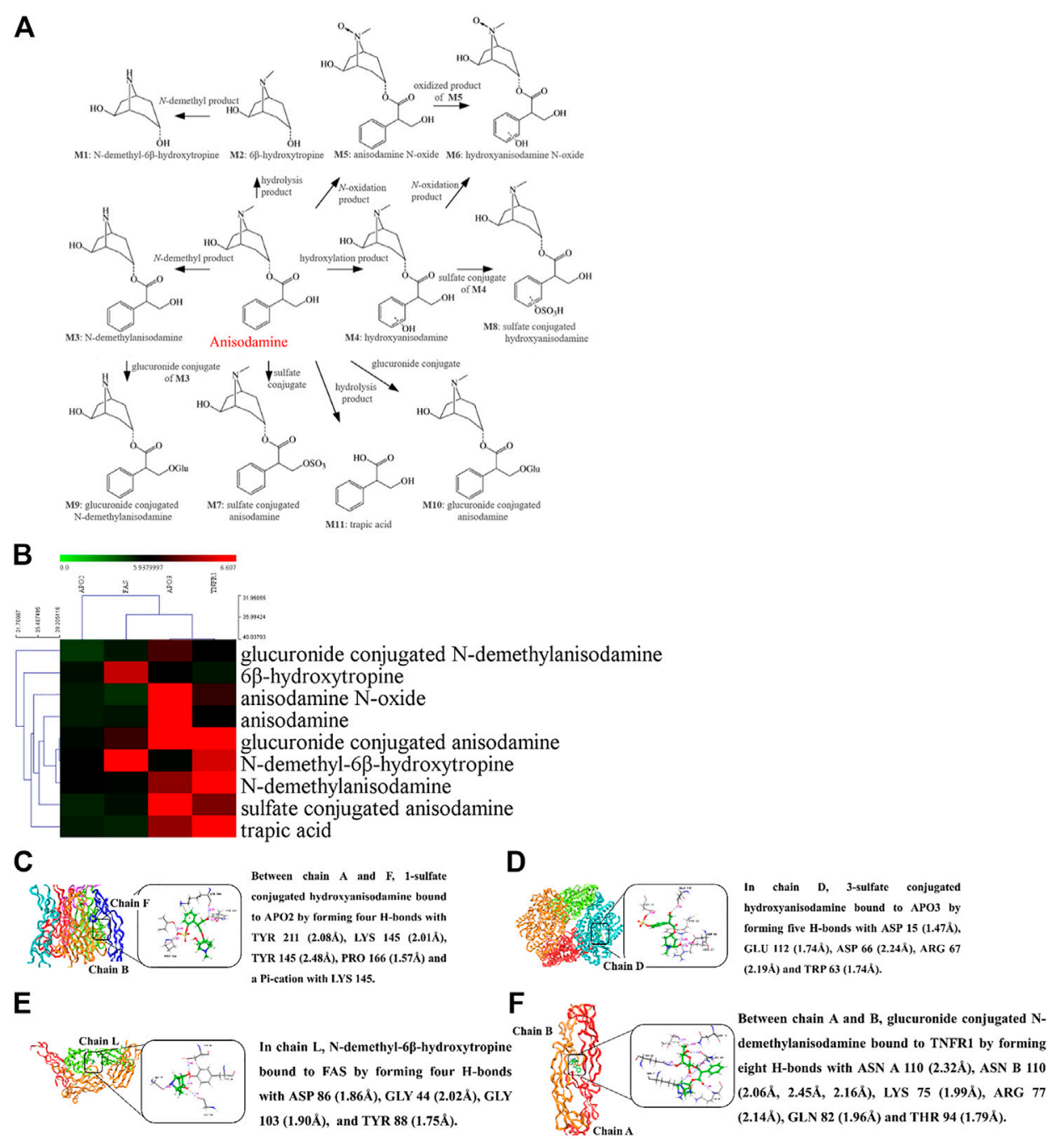

FIGURE 3 | Molecular docking of anisodamine binding with apoptosis receptor of endothelial cells.

base proteins (MBP) from eosinophils, Eos cationic protein (ECP), and Eos-derived neurotoxin (EDN), leading to further uncontrolled inflammatory responses. However, the nonimmune cells are mainly parenchymal cells of the liver, lung, and intestine (Suzuki et al., 2011; Liu H. et al., 2015; Guo et al., 2019), while cardiomyocytes (Liu et al., 2013; Zhang et al., 2015; Tian et al., 2019) and nerve cells (Peña et al., 2011; Reichardt et al., 2017) of apoptosis have also been reported.

\section{ANTI-APOPTOSIS MECHANISM OF HERBAL MEDICINE IN ENDOTOXEMIA}

It has been observed that various herbal ingredients can improve the healing of endotoxemia, not only through anti-inflammatory effects, but also through their regulation of apoptosis in many types of immune cells (including lymphocytes and macrophages), endothelial cells, and parenchymal cells in different solid organs, especially heart, liver, and lung (Cheng et al., 2014). Although apoptosis has been extensively studied in various diseases such as cancer, neurodegenerative diseases, and HIV infection, its role in sepsis and its regulation as a novel therapeutic approach in the treatment of endotoxemia has attracted attention in recent years.

\section{Sanhuang Xiexin Decoction and Its Metabolites}

Sanhuang Xiexin decoction was firstly described in the Synopsis of Golden Chamber by Zhongjing Zhang of the Eastern Han Dynasty and is a classical formula widely used in Chinese medicine to treat fire and detoxify. It is composed of Rhizoma Rhei (Rheum palmatum L.), Rhizoma Coptidis (Coptis chinensis Franch), and Radix Scutellaria (Scutellaria baicalensis Georgi). Previous studies have shown that Sanhuang Xiexin Decoction has effective therapeutic effects on endotoxemia through antiinflammation (Lo et al., 2005a; Lo et al., 2005b). Other recent studies have shown that it also possesses potent anti-apoptotic activity. The main anti-apoptotic ingredients are aloe-emodin, 


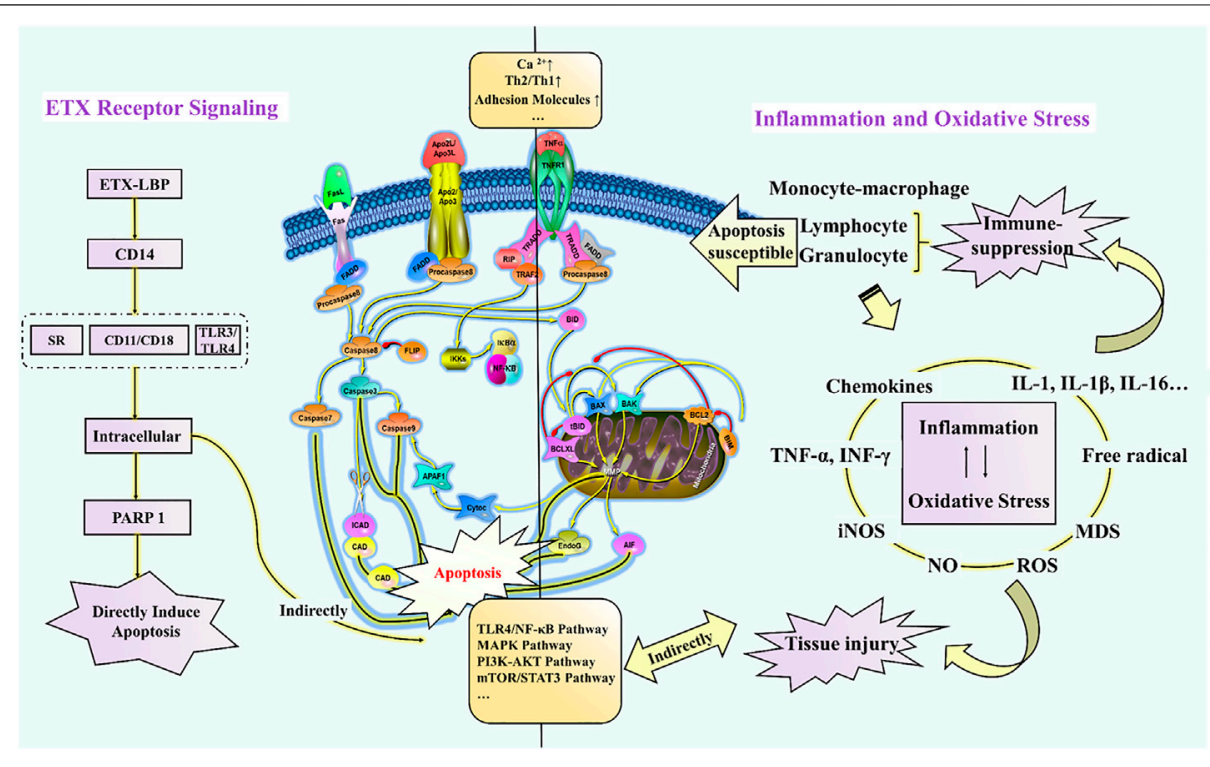

FIGURE 4 | Schematic diagram of the molecular mechanism of endotoxin-induced apoptosis.

coptisine, and baicalin. Figure 2 depicts its formula and the metabolic steps and products of coptisine and baicalin in vivo. For example, aloe-emodin can attenuate myocardial infarction and cardiomyocyte apoptosis (Yu et al., 2019). The metabolites are rhein, aloe-emodin sulfates/glucuronides, and rhein sulfates/ glucuronides ( $Y u$ et al., 2016). Among them, rhein exhibited significant anti-apoptosis in endotoxemia and showed significant protective effects against endotoxin-induced kidney injury (Yu et al., 2015). Coptisine, a major compound from Rhizoma Coptidis that clears heat and dampness, purging fire for removing the toxin has been reported to exhibit protective effects on HaCaT keratinocytes by blocking the mitochondriadependent apoptotic pathway (Choi, 2019). Furthermore, baicalin is the most reported anti-apoptotic component of Sanhuang Xiexin Decoction, showing anti-apoptotic effects in a variety of cell types, including cardiomyocytes (Liou et al., 2011; Liou et al., 2012), C2C12 myoblast (Pan et al., 2019), arterial endothelial cells (Shou et al., 2017), neuronal cells (Zheng, et al., 2015), hepatic stellate cells (Wu et al., 2018a; Wu et al., 2018b), endplate chondrocytes (Pan et al., 2017), renal cells (Zhu et al., 2016) and colonic epithelial cells (Yao et al., 2016). Baicalein 6-O- $\beta$-D-glucopyranuronoside (Akao et al., 2013) and baicalein (Wang et al., 2015) are the main metabolites of baicalin that inhibit the apoptosis of intestinal epithelial cells, thus reducing the chance of endotoxemia in cirrhosis (Liu Y. et al., 2015) and cardiomyocyte injury (Zhu et al., 2019).

\section{Molecular Docking Prediction of Anisodamine for Anti-Apoptotic Treatment of Endotoxemia}

Anisodamine is a well-known natural product that is widely used to improve the survival of patients with septic shock. The binding capacity of anisodamine and its 23 intracorporal metabolites
(Chen et al., 2005) to endothelial cell apoptosis-related receptors was evaluated by molecular docking technology. As shown in Figure 3, anisodamine and its metabolites bind mainly to TNFR1 and APO3 with high affinity. Other individual metabolites, such as $\mathrm{N}$-demethyl-6 beta hydroxytropine and 1sulfate conjugated hydroxyanisodamine also bind to FAS and APO2 with strong affinity. Thus, the therapeutic effect of anisodamine on endotoxemia involves molecular mechanisms associated with apoptosis. However, further evaluation regarding the molecular mechanisms of anisodamine in vitro and in vivo is necessary.

\section{Other Anti-Apoptosis Ingredients Derived From Herbal Medicines}

As seen in Figure 4, immune paralysis and organ damage are the main culprits for the poor prognosis of endotoxemia. Many herbal ingredients are effective in the treatment of endotoxemia by inhibiting apoptosis. Their effects, target organs/cells, dosage, relevant targets, and indications have been summarized in Table 1 . The activation of the TLR4/NF- $\kappa B$ pathway leads to exacerbation of inflammation and apoptosis, which in turn leads to worsening endotoxemia. Therefore, inhibition of inflammation, oxidative stress, and apoptosis is a new research focus in the treatment of endotoxemia (Guan et al., 2019; Li et al., 2019; Zhao et al., 2020).

Meng et al. confirmed that sanguinarine attenuates ETXinduced inflammation and apoptosis by blocking the TLR4/NF$\kappa B$ pathway (Meng et al., 2018). However, in general, the mechanism of herbal ingredients based on this pathway for the treatment of endotoxemia is less studied, and it remains to be verified whether the inhibition of this pathway signal can be used to evaluate and screen potential herbal ingredients. Furthermore, leukocyte adhesion molecules have been suggested as new targets 
TABLE 1 | Effect of herbal ingredients on anti-apoptosis related pathway molecular (excepted those mentioned in the text).

\begin{tabular}{|c|c|c|c|c|}
\hline Herbal medicine & Effects & Related targets & $\begin{array}{l}\text { Endotoxemia } \\
\text { related indications }\end{array}$ & References \\
\hline Punicalagin (PNG) & $\begin{array}{l}\text { Anti-apoptosis, nephroprotection, anti- } \\
\text { inflammation, anti-oxidant }\end{array}$ & $\begin{array}{l}\downarrow \text { : Serum Cr, NGAL, KIM-1, IL-18, } \\
\text { TNF- } \alpha, \text { IL-6; MDA, NO, MPO, iNOS. } \\
\text { Bax/Bcl2, caspase-3/-8/-9 }\end{array}$ & $\begin{array}{l}\text { Sepsis complication of acute } \\
\text { kidney injury }\end{array}$ & $\begin{array}{l}\text { Fouad et al. } \\
(2016)\end{array}$ \\
\hline Thaliporphine & $\begin{array}{l}\text { Anti-inflammation, anti-apoptosis; } \\
\text { radioprotection }\end{array}$ & $\begin{array}{l}\downarrow: \text { p38/NF-kB pathway; TNF-a, } \\
\text { caspase 3, serum cTnl, LDH, Reverse } \\
\text { steeper EDPVR, Gentler ESPVR } \\
\uparrow: \text { PI3K/Akt/mTOR pathway }\end{array}$ & Cardiac depression & Lee et al. (2010) \\
\hline Apocynin & $\begin{array}{l}\text { Hepatocyte protection, anti-apoptosis, } \\
\text { anti-oxidation }\end{array}$ & $\begin{array}{l}\downarrow \text { : Hydroperoxides, MDA, SOD, } \\
\text { NADPH, POX } \\
\uparrow: \text { CAT, SOD, G-POX }\end{array}$ & Endotoxemia & Ben et al. (2000) \\
\hline Stevioside & $\begin{array}{l}\text { Anti-apoptosis, anti-oxidation, anti- } \\
\text { inflammation, immunoregulation }\end{array}$ & $\begin{array}{l}\downarrow: \text { SOD, CAT, GSH, MDA, NO, DPPH; } \\
\text { TNF- } \alpha, \text { IL-1 } \beta, I L-6 \\
\uparrow: \text { AST, ALT }\end{array}$ & Acute liver injury & Latha et al. (2017) \\
\hline Soybean oil, olive oil & Anti-inflammation, immunoregulation & $\begin{array}{l}\downarrow \text { : Mitochondrial pathway, Apoptosis } \\
\text { of lymphocyte, Caspase-8, Bax, Bcl- } \\
\text { xl, caspase-3, TNF- } \alpha \text {, IL-6 } \\
\uparrow: \text { PI3K/Akt phosphorylation }\end{array}$ & $\begin{array}{l}\text { Sepsis complications of acute } \\
\text { lung injury and acute respiratory } \\
\text { distress syndrome }\end{array}$ & Bi et al. (2010) \\
\hline Cordyceps sinensis & $\begin{array}{l}\text { Anti-apoptosis, anti-inflammation, } \\
\text { immunoregulation }\end{array}$ & $\begin{array}{l}\downarrow: \text { NF- } \kappa B, T N F-\alpha, \text { AST, NO, AST, } \\
\text { caspase-3/-6, PARP } \\
\uparrow: \text { Phosphorylation of MAPK (ERK1/2), } \\
\text { SOD, IL-10 }\end{array}$ & $\begin{array}{l}\text { Sepsisshock complication of } \\
\text { hepaticdysfunction }\end{array}$ & $\begin{array}{l}\text { Chen and Wu. } \\
\text { (2014) }\end{array}$ \\
\hline Garlic & $\begin{array}{l}\text { Anti-inflammation, pro-apoptosis, } \\
\text { immunoregulation, anti-platelet, anti- } \\
\text { hypertension, antioxidation }\end{array}$ & $\begin{array}{l}\downarrow \text { : TNF-a, IL-6 } \\
\uparrow: \text { IL-10, sTRAIL/Apo-2L }\end{array}$ & Preeclampsia & $\begin{array}{l}\text { Makris et al. } \\
(2005)\end{array}$ \\
\hline Salvia miltiorrhizae & $\begin{array}{l}\text { Improve microcirculation, anti- } \\
\text { inflammation, antioxidation, anti- } \\
\text { apoptosis, mucosal protection, } \\
\text { macrophage protection }\end{array}$ & $\downarrow:$ p65NF-кB, PLA2, Bax & $\begin{array}{l}\text { Severe acute pancreatitis; } \\
\text { obstructive jaundice }\end{array}$ & $\begin{array}{l}\text { Zhang et al. } \\
\text { (2009) }\end{array}$ \\
\hline Sophocarpine & $\begin{array}{l}\text { Anti-inflammation, anti-apoptosis, } \\
\text { antioxidation }\end{array}$ & 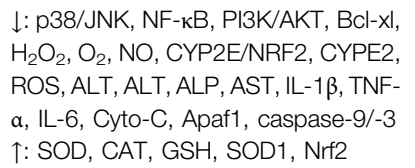 & Septicliver injury & $\begin{array}{l}\text { Zheng et al. } \\
\text { (2018) }\end{array}$ \\
\hline Astragalusroot & $\begin{array}{l}\text { Cytoprotection, anti-apoptosis, } \\
\text { immunoregulation }\end{array}$ & $\begin{array}{l}\downarrow: \text { ROS, caspase-3, p53, } \\
\text { mitochondrial membrane } \\
\text { depolarization } \\
\uparrow: \text { Bcl2 }\end{array}$ & Endotoxemia & Wu et al. (2019) \\
\hline Astragalin & $\begin{array}{l}\text { Antioxidation, anti-apoptosis, anti- } \\
\text { inflammation, antianaphylaxis }\end{array}$ & $\begin{array}{l}\downarrow \text { : NF-кB, MAPK, TLR4, JNK } \\
\text { pathways; eotaxin-1, ROS, caspase- } \\
\text { 3, NADPH, PLC } \gamma 1-P K C \beta 2-N A D P H \\
\uparrow: \text { Akt, ERK }\end{array}$ & $\begin{array}{l}\text { Allergic airway diseases; } \\
\text { peribronchial eosinophilia }\end{array}$ & Cho et al. (2014) \\
\hline Matrine & $\begin{array}{l}\text { Anti-inflammation, antioxidation, anti- } \\
\text { fibrosis, antiviral }\end{array}$ & $\begin{array}{l}\downarrow \text { : NF-кB, MIP-2, MPO, MDA, TNF- } \alpha \text {, } \\
\text { IL-6, IL-8, ALT, AST, LDH, ALP, NO, } \\
\text { sICAM-1, caspase-3 }\end{array}$ & $\begin{array}{l}\text { Acute liver injury, } \\
\text { Hepaticischemia }\end{array}$ & $\begin{array}{l}\text { Zhang et al. } \\
(2011)\end{array}$ \\
\hline $\begin{array}{l}\text { Green teapolyphenols, } \\
\text { catechins, flavandiols, flavanols, } \\
\text { phenolicacids }\end{array}$ & $\begin{array}{l}\text { Anti-apoptosis, geno protective, } \\
\text { antioxidation }\end{array}$ & $\begin{array}{l}\downarrow: \text { AST, ALT, TB, ALB, NO } \\
\uparrow: \text { TAC }\end{array}$ & Liver damage & Allam et al. (2017) \\
\hline Siniinjection & Anti-apoptosis & $\begin{array}{l}\text { \: MABP, iNOS, PI, IL-6, IL-18, ET- } \\
\text { 1, NO }\end{array}$ & Septic shock & Pei et al. (2013) \\
\hline $\begin{array}{l}\text { 12-O-Tetradecanoyl-phorbol } \\
\text { 13-Acetate (TPA) }\end{array}$ & Anti-apoptosis & $\begin{array}{l}\downarrow: \text { NF-кB } \\
\uparrow: \text { C/EBP, p38 MAPK }\end{array}$ & Endotoxemia & Sunil et al. (2002) \\
\hline Strawberry & $\begin{array}{l}\text { Anti-inflammation, antioxidation, anti- } \\
\text { apoptosis }\end{array}$ & 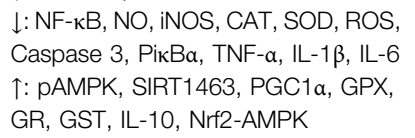 & $\begin{array}{l}\text { Human dermalfibroblast } \\
\text { Inflammationliver injury }\end{array}$ & $\begin{array}{l}\text { Gasparrin et al. } \\
\text { (2018) }\end{array}$ \\
\hline Betulinicacidderivative BA5 & Immunoregulation & 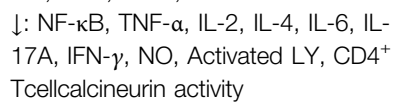 & Delayed hypersensitivity & Meira et al. (2017) \\
\hline $\begin{array}{l}\text { Garlic oildiallyldisulfide diallyl } \\
\text { trisulfide }\end{array}$ & $\begin{array}{l}\text { Anti-inflammation, antioxidation, anti- } \\
\text { apoptosis }\end{array}$ & $\downarrow$ : nitrate/nitrite & Intestinaldamage & $\begin{array}{l}\text { Chiang et al. } \\
\text { (2006) }\end{array}$ \\
\hline $\begin{array}{l}\text { Rubiaceae-typecyclo-peptide } \\
\text { (RA-V) }\end{array}$ & Anti-inflammation & 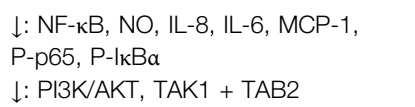 & Septic shock & $\begin{array}{l}\text { Wang et al. } \\
(2018)\end{array}$ \\
\hline
\end{tabular}


TABLE 1 | (Continued) Effect of herbal ingredients on anti-apoptosis related pathway molecular (excepted those mentioned in the text).

\begin{tabular}{|c|c|c|c|c|}
\hline Herbal medicine & Effects & Related targets & $\begin{array}{l}\text { Endotoxemia } \\
\text { related indications }\end{array}$ & References \\
\hline $\begin{array}{l}\text { Cinnamaldehyde (CA) } \\
\text { Linalool (LIN) }\end{array}$ & Anti-inflammation & $\begin{array}{l}\downarrow \text { : NF-кB, TLR4/MD2, MyD88, } \\
\text { NLRP3, ASC, caspase- } 1, \text { TNF- } \alpha, \text { IL- } \\
1 \beta \text {, IL-18, nitrate/nitrite, IFN- } \gamma \text {, } \\
\text { HMGB-1 }\end{array}$ & Endotoxemia & Lee et al. (2018) \\
\hline $\begin{array}{l}\text { Gryllusbimaculatus } \\
\text { Extracts (GBE) }\end{array}$ & $\begin{array}{l}\text { Anti-apoptosis, anti-inflammation, } \\
\text { antioxidation }\end{array}$ & $\begin{array}{l}\downarrow \text { : ROS, NO, IL-6, TNF- } \alpha, \text { TG, TLR4, } \\
\text { P-JNK, P-p38, OHdG, p-MLCK, } \\
\text { p-ROCK, p-srcFK }\end{array}$ & $\begin{array}{l}\text { Alcoholic liver diseases } \\
\text { Intestinal inflammation }\end{array}$ & $\begin{array}{l}\text { Hwang et al. } \\
\text { (2019) }\end{array}$ \\
\hline Scytonemin & Antiproliferative & $\begin{array}{l}\downarrow \text { : cdc25C, p-cdc25C, Cell } \\
\text { cycleregulatory kinases, GST-PLK, } \\
\text { GST-Tie2, Protein kinase A, Protein } \\
\text { kinase C } 32 \text {, CDK1/cyclin B, GST- } \\
\text { Myt1, GST-checkpoint kinase 1, GST- } \\
\text { polo-like kinase } 1\end{array}$ & Endotoxemia & $\begin{array}{l}\text { Stevensonet al. } \\
(2002)\end{array}$ \\
\hline
\end{tabular}

for the development of anti-inflammatory agents (Mukaida et al., 1996), which is mainly attributed to the enhancement of TNFa-induced apoptosis by $\beta 2$ integrins (CD11/CD18) at 4 and $8 \mathrm{~h}$ after ETX stimulation (Walzog et al., 1997). Moreover, free total rhubarb anthraquinones (FTRAs) attenuated intestinal injury and enhanced intestinal barrier function by regulating intestinal immune function in rats with endotoxin-induced acute pancreatitis (Xiong, et al., 2018). In addition, endotoxemia can also induce apoptosis through oxidative stress. For example, piperlongumine exhibits prominent anti-inflammatory effects by inhibiting the ETX-induced p65 NF$\kappa \mathrm{B}$ signaling cascade and markedly suppresses cytokine storm production, which is closely associated with ROS-mediated induction of late apoptosis and reduced expression of antiapoptotic Bcl2 protein (Thatikonda et al., 2020). To sum up, Figure 4 reveals how the recognition signals of endotoxin, inflammation, and oxidative stress responses induce apoptosis directly or indirectly. These herb ingredients show significant therapeutic effects on endotoxin, inhibiting endotoxin-induced elevation in $\mathrm{Ca}^{2+}$ and adhesion factors, and activation of signaling pathways such as TLR4/NF- $\mathrm{B}, \mathrm{MAPK}, \mathrm{PI} 3 \mathrm{~K}-\mathrm{AKT}$, and mTOR/STAT3.

\section{FUTURE PROSPECTS}

In conclusion, numerous studies have shown that the antiapoptotic treatment of endotoxemia can improve immunosuppression and protect parenchymal organ function. A range of bacterial components such as ETX can induce a cellular stress response and induce apoptosis. However, ETX, as a caspase inhibitor, can inhibit apoptosis by engaging its $\mathrm{O}$-antigen $(\mathrm{O} \mathrm{Ag})$ moiety to directly bind caspases, contributing to the successful colonization of bacteria to support their intracellular propagation (Günther et al., 2019), but to the detriment of humans. In addition, it is interesting to note that many anti-apoptotic herbal ingredients in endotoxemia exhibit pro-apoptotic activity in cancer. For example, salidroside increases survival in endotoxemic mice (Guan et al., 2011) and has been reported to inhibit apoptosis in bone marrow mesenchymal stem cells (Wei et al., 2013), H9c2 cardiomyocytes
(Sun et al., 2018), pulmonary arterial smooth muscle cells (Gui et al., 2017), pheochromocytoma cells (Hu et al., 2016), neural stem cells (Yan et al., 2018), cardiomyocytes (Zhu et al., 2015) and umbilical vein endothelial cells (Chen and $\mathrm{Wu}, 2014$ ), while inducing apoptosis in colorectal cancer cells (Fan et al., 2016) gastric cancer AGS cells (Rong et al., 2020). It is thus clear that anti-apoptosis is not a single effective approach for the treatment of endotoxemia with herbal medicine, but must be combined with anti-inflammation, antioxidative stress, and anticoagulation to improve the prognosis of patients with endotoxemia. In addition, it should be noted that the anti-apoptotic activity of herb ingredients is also affected by the pathological state of the host. In any case, anti-apoptotic therapy plays an important role in endotoxemia but has long been neglected, and a considerable number of experimental studies on endotoxemia do not involve the detection of apoptotic-related indicators. This suggests that the impact of apoptosis on the pathophysiological process of endotoxemia should be emphasized and that antiapoptosis is a potential new approach for the treatment of endotoxemia.

\section{AUTHOR CONTRIBUTIONS}

ZL conceived the study. WW, JL, YinZ, YuZ, and GQ reviewed and summarized the literature. ZL wrote the manuscript and created all the figures. $\mathrm{XM}$ and $\mathrm{YiZ}$ paid all fees for the publication of this manuscript. YiZ, XM, and XS supervised the study and gave final approval for the published version. The final version of the manuscript was read and approved by all authors.

\section{FUNDING}

This work was supported by the National Natural Science Foundation of China (81773974), the National Key R\&D program of China (2017YFC1703904), the Science and Technology Department of Sichuan Province (19SYXHZ0095, 2018JY0467). 


\section{REFERENCES}

Akao, T., Sato, K., He, J.-X., Ma, C.-M., and Hattori, M. (2013). Baicalein 6-O- $\beta$-dGlucopyranuronoside is a main metabolite in the plasma after oral administration of baicalin, a flavone glucuronide of scutellariae Radix, to rats. Biol. Pharm. Bull. 36 (5), 748-753. doi:10.1248/bpb.b12-00850

Allam, A. A., Gabr, S., Ajarem, J., Alghadir, A., Sekar, R., and Chow, B. K. (2017). Geno protective and anti-apoptotic effect of green tea against perinatal lipopolysaccharide-exposure induced liver toxicity in rat newborns. Ajtcam 14 (2), 166-176. doi:10.21010/ajtcam.v14i2.18

Ben, S. V., Lomnitski, L., Nyka, A., Carbonatto, M., Peano, S., Zurovsky, Y., et al. (2000). Effect of natural antioxsidants and apocynin on LPS-induced endotoxemia in rabbit. Hum. Exp. Toxicol. 19 (11), 604-614. doi:10.1191/ 096032700666138364

Bi, M. H., Ott, J., Fischer, T., Hecker, M., Dietrich, H., Schaefer, M. B., et al. (2010). Induction of lymphocyte apoptosis in a murine model of acute lung injurymodulation by lipid emulsions. Shock 33 (2), 179-188. doi:10.1097/shk. 0b013e3181ac4b3b

Brenchley, J. M. (2006). Microbial translocation is a cause of systemic immune activation in chronic HIV infection. Retrovirology 3 (1 Suppl. ment), S98. doi:10.1186/1742-4690-3-s1-s98

Chen, H. X., Wang, H., Chen, Y., and Zhang, H. S. (2005). Liquid chromatographytandem mass spectrometry analysis of anisodamine and its phase I and II metabolites in rat urine. J. Chromatogr. B Analyt. Technol. Biomed. Life Sci. 824, 21-29. doi:10.1016/j.jchromb.2005.07.036

Chen, Z., and Wu, X. (2014). Salidroside attenuates high glucose-induced apoptosis in human umbilical vein endothelial cells via activating the $\mathrm{Ca}(2)+/ \mathrm{CaM} /$ CAMKII//eNOS pathway. Zhonghua Xin Xue Guan Bing Za Zhi 42 (4), 327-333. doi:10.3760/cma.j.issn.0253-3758.2014.04.013

Cheng, Y.-J., Cheng, S.-M., Teng, Y.-H., Shyu, W.-C., Chen, H.-L., and Lee, S.-D. (2014). Cordyceps sinensisPrevents apoptosis in mouse liver with D-galactosamine/lipopolysaccharide-induced fulminant hepatic failure. Am. J. Chin. Med. 42 (2), 427-441. doi:10.1142/s0192415x14500281

Chiang, Y.-H., Jen, L.-N., Su, H.-Y., Lii, C.-K., Sheen, L.-Y., and Liu, C.-T. (2006). Effects of garlic oil and two of its major organosulfur compounds, diallyl disulfide and diallyl trisulfide, on intestinal damage in rats injected with endotoxin. Toxicol. Appl. Pharmacol. 213 (1), 46-54. doi:10.1016/j.taap.2005. 08.008

Cho, I. H., Gong, J. H., Kang, M. K., Lee, E. J., Park, J. H., Park, S. J., et al. (2014). Astragalin inhibits airway eotaxin-1 induction and epithelial apoptosis through modulating oxidative stress-responsive MAPK signaling. BMC Pulm. Med. 14, 122. doi:10.1186/1471-2466-14-122

Choi, Y. H. (2019). Activation of the Nrf2/HO-1 signaling pathway contributes to the protective effects of coptisine against oxidative stress-induced DNA damage and apoptosis in HaCaT keratinocytes. gpb 38 (4), 281-294. doi:10.4149/ gpb_2019014

Coureuil, M., Bourdoulous, S., Marullo, S., and Nassif, X. (2014). Invasive meningococcal disease: a disease of the endothelial cells. Trends Mol. Med. 20 (10), 571-578. doi:10.1016/j.molmed.2014.08.002

Danial, N. N., and Korsmeyer, S. J. (2004). Cell death. Cell 116 (2), 205-219. doi:10. 1016/s0092-8674(04)00046-7

Deitch, E. A. (2012). Gut-origin sepsis: evolution of a concept. The Surgeon 10 (6), 350-356. doi:10.1016/j.surge.2012.03.003

Eduardo, L. C., and Fresno, C. D. (2013). Pathophysiology of endotoxin tolerance: mechanisms and clinical consequences. Crit. Care 17 (6), 242. doi:10.1186/ cc13110

Erridge, C. (2011). Diet, commensals and the intestine as sources of pathogenassociated molecular patterns in atherosclerosis, type 2 diabetes and nonalcoholic fatty liver disease. Atherosclerosis 216 (1), 1-6. doi:10.1016/j. atherosclerosis.2011.02.043

Fan, X.-J., Wang, Y., Wang, L., and Zhu, M. (2016). Salidroside induces apoptosis and autophagy in human colorectal cancer cells through inhibition of PI3K/ Akt/mTOR pathway. Oncol. Rep. 36 (6), 3559-3567. doi:10.3892/or.2016. 5138

Fehsel, K., Kröncke, K. D., Meyer, K. L., Huber, H., Wahn, V., and Kolb-Bachofen, V. (1995). Nitric oxide induces apoptosis in mouse thymocytes. J. Immunol. 155 (6), 2858-2865
Fouad, A. A., Qutub, H. O., and Al-Melhim, W. N. (2016). Nephroprotection of punicalagin in rat model of endotoxemic acute kidney injury. Toxicol. Mech. Methods 26 (7), 538-543. doi:10.1080/15376516.2016.1211207

Gasparrini, M., Giampieri, F., Forbes-Hernandez, T. Y., Afrin, S., Cianciosi, D., Reboredo-Rodriguez, P., et al. (2018). Strawberry extracts efficiently counteract inflammatory stress induced by the endotoxin lipopolysaccharide in human dermal fibroblast. Food Chem. Toxicol. 114, 128-140. doi:10.1016/j.fct.2018. 02.038

Guan, F., Zhou, X., Li, P., Wang, Y., Liu, M., Li, F., et al. (2019). MG53 attenuates lipopolysaccharide-induced neurotoxicity and neuroinflammation via inhibiting TLR4/NF- $\mathrm{kB}$ pathway in vitro and in vivo. Prog. NeuroPsychopharmacol. Biol. Psychiatry 95, 109684. doi:10.1016/j.pnpbp.2019. 109684

Guan, S., Feng, H., Song, B., Guo, W., Xiong, Y., Huang, G., et al. (2011). Salidroside attenuates LPS-induced pro-inflammatory cytokine responses and improves survival in murine endotoxemia. Int. Immunopharmacol. 11 (12), 2194-2199. doi:10.1016/j.intimp.2011.09.018

Gui, D., Cui, Z. M., Zhang, L., Yu, C., Yao, D., Xu, M., et al. (2017). Salidroside attenuates hypoxia-induced pulmonary arterial smooth muscle cell proliferation and apoptosis resistance by upregulating autophagy through the AMPK-mTOR-ULK1 pathway. BMC Pulm. Med. 17 (1), 191. doi:10. 1186/s12890-017-0477-4

Günther, S. D., Fritsch, M., Seeger, J. M., Schiffmann, L. M., Snipas, S. J., Coutelle, M., et al. (2019). Cytosolic Gram-negative bacteria prevent apoptosis by inhibition of effector caspases through lipopolysaccharide. Nat. Microbiol. 5 (2), 354-367. doi:10.1038/s41564-019-0620-5

Guo, J. M., Liu, Z., Zhang, D. f., Chen, Y. Y., Qin, H. R., Liu, T. T., et al. (2019). TLR4 agonist monophosphoryl lipid A alleviated radiation-induced intestinal injury. J. Immunol. Res. 2009, 2121095. doi:10.1155/2019/2121095

Harjai, M., Bogra, J., Kohli, M., and Pant, A. B. (2013). Is suppression of apoptosis a new therapeutic target in sepsis?. Anaesth. Intensive Care 41 (2), 175-183. doi:10.1177/0310057x1304100207

Hengartner, M. O. (2000). The biochemistry of apoptosis. Nature 407 (6805), 770-776. doi:10.1038/35037710

Hotchkiss, R. S., Coopersmith, C. M., and Karl, I. E. (2005). Prevention of lymphocyte apoptosis-a potential treatment of sepsis?. Clin. Infect. Dis. 41, 465-469. doi:10.1086/431998

Hotchkiss, R. S., Tinsley, K. W., Swanson, P. E., and Karl, I. E. (2002). Endothelial cell apoptosis in sepsis. Crit. Care Med. 30, 225-228. doi:10.1097/00003246200205001-00009

Hu, Y., Lv, X., Zhang, J., and Meng, X. (2016). Comparative study on the protective effects of salidroside and hypoxic preconditioning for attenuating anoxiainduced apoptosis in pheochromocytoma (PC12) cells. Med. Sci. Monit. 22, 4082-4091. doi:10.12659/msm.897640

Hwang, B. B., Chang, M. H., Lee, J. H., Heo, W., Kim, J. K., Pan, J. H., et al. (2019). The edible insect Gryllus bimaculatus protects against gut-derived inflammatory responses and liver damage in mice after acute alcohol exposure. Nutrients 11 (4), E857. doi:10.3390/nu11040857

Jäättelä, M., and Tschopp, J. (2003). Caspase-independent cell death in T lymphocytes. Nat. Immunol. 4 (5), 416-423. doi:10.1038/ni0503-416

Kerr, J. F. R., Wyllie, A. H., and Currie, A. R. (1972). Apoptosis: a basic biological phenomenon with wideranging implications in tissue kinetics. Br. J. Cancer 26 (4), 239-257. doi:10.1038/bjc.1972.33

Latha, S., Chaudhary, S., and Ray, R. S. (2017). Hydroalcoholic extract of Stevia rebaudiana bert. leaves and stevioside ameliorates lipopolysaccharide induced acute liver injury in rats. Biomed. Pharmacother. 95, 1040-1050. doi:10.1016/j. biopha.2017.08.082

Lee, A. S., Chen, W. P., Kuo, Y. L., Ho, Y. J., Lee, S. S., and Su, M. J. (2010). Thaliporphine preserves cardiac function of endotoxemic rabbits by both directly and indirectly attenuating NFKB signaling pathway. Plos One 7 (6), e39174. doi:10.1371/journal.pone.0039174

Lee, S.-C., Wang, S.-Y., Li, C.-C., and Liu, C.-T. (2018). Anti-inflammatory effect of cinnamaldehyde and linalool from the leaf essential oil of Cinnamomum osmophloeum Kanehira in endotoxin-induced mice. J. Food Drug Anal. 26 (1), 211-220. doi:10.1016/j.jfda.2017.03.006

Leist, M., and Jäättelä, M. (2001). Four deaths and a funeral: from caspases to alternative mechanisms. Nat. Rev. Mol. Cel Biol. 2 (8), 589-598. doi:10.1038/ 35085008 
Li, C., Li, L., Chen, K., Wang, Y., Yang, F. X., and Wang, G. (2019). UFL1 alleviates lipopolysaccharide-induced cell damage and inflammation via regulation of the TLR4/NF- $\mathrm{BB}$ pathway in bovine mammary epithelial cells. Oxid. Med. Cel Longev. 2019, 6505373. doi:10.1155/2019/6505373

Li, L., Wan, G., Han, B., and Zhang, Z. (2018). Echinacoside alleviated LPS-induced cell apoptosis and inflammation in rat intestine epithelial cells by inhibiting the mTOR/STAT3 pathway. Biomed. Pharmacother. 104, 622-628. doi:10.1016/j. biopha.2018.05.072

Liou, S.-F., Hsu, J.-H., Liang, J.-C., Ke, H.-J., Chen, I.-J., Wu, J.-R., et al. (2012). SanHuang-Xie-Xin-Tang protects cardiomyocytes against hypoxia/reoxygenation injury via inhibition of oxidative stress-induced apoptosis. J. Nat. Med. 66 (2), 311-320. doi:10.1007/s11418-011-0592-0

Liou, S.-F., Ke, H.-J., Hsu, J.-H., Liang, J.-C., Lin, H.-H., Chen, I.-J., et al. (2011). San-huang-xie-xin-tang prevents rat hearts from ischemia/reperfusion-induced apoptosis through eNOS and MAPK pathways. Evidence-Based Complement. Altern. Med. 2011, 1. doi:10.1093/ecam/neq061

Liu, H., Yu, X., Yu, S., and Kou, J. (2015). Molecular mechanisms in lipopolysaccharide-induced pulmonary endothelial barrier dysfunction. Int. Immunopharmacol. 29 (2), 937-946. doi:10.1016/j.intimp.2015.10.010

Liu, L., Wang, P., Liang, C., He, D., Yu, Y., and Liu, X. (2013). Distinct effects of Nampt inhibition on mild and severe models of lipopolysaccharide-induced myocardial impairment. Int. Immunopharmacol. 17 (2), 342-349. doi:10.1016/ j.intimp.2013.06.017

Liu, Y., Ye, F., Zou, W. J., Sun, Y., Wang, R., Han, P. P., et al. (2015). Baicalein reduces the occurrence of cirrhotic endotoxemia by reducing intestinal mucosal apoptosis. BMC Complement. Altern. Med. 15, 161. doi:10.1186/s12906-0150682-8

Lo, Y. C., Lin, Y. L., Yu, K. L., Lai, Y. H., Wu, Y. C., Ann, L. M., et al. (2005a). SanHuang-Xie-Xin-Tang attenuates inflammatory responses in lipopolysaccharide-exposed rat lungs. J. Ethnopharmacol. 101 (1-3), 68-74. doi:10.1016/j.jep.2005.03.015

Lo, Y. C., Tsai, P. L., Huang, Y. B., Shen, K. P., Tsai, Y. H., Wu, Y. C., et al. (2005b). San-Huang-Xie-Xin-Tang reduces lipopolysaccharides-induced hypotension and inflammatory mediators. J. Ethnopharmacol. 96 (1-2), 99-106. doi:10. 1016/j.jep.2004.09.023

Makris, A., Thornton, C. E., Xu, B., and Hennessy, A. (2005). Garlic increases IL-10 and inhibits TNFa and IL-6 production in endotoxin-stimulated human placental explants. Placenta 26 (10), 828-834. doi:10.1016/j.placenta.2004. 10.019

Manco, M., Putignani, L., and Bottazzo, G. F. (2010). Gut microbiota, lipopolysaccharides, and innate immunity in the pathogenesis of obesity and cardiovascular risk. Endocr. Rev. 31 (6), 817-844. doi:10.1210/er.20090030

Meira, C. S., Espírito Santo, R. F. d., dos Santos, T. B., Orge, I. D., Silva, D. K. C., Guimarães, E. T., et al. (2017). Betulinic acid derivative BA5, a dual NF-kB/ calcineurin inhibitor, alleviates experimental shock and delayed hypersensitivity. Eur. J. Pharmacol. 815, 156-165. doi:10.1016/j.ejphar.2017.09.008

Meng, Y.-y., Liu, Y., Hu, Z.-f., Zhang, Y., Ni, J., Ma, Z.-g., et al. (2018). Sanguinarine attenuates lipopolysaccharide-induced inflammation and apoptosis by inhibiting the TLR4/NF-kB pathway in H9c2 cardiomyocytes. Curr. Med. Sci. 38 (2), 204-211. doi:10.1007/s11596-018-1867-4

Micheau, O., and Jürg, T. (2003). Induction of tnf receptor i-mediated apoptosis via two sequential signaling complexes. Cell 114 (2), 0-190. doi:10.1016/s00928674(03)00521-x

Mukaida, N., Ishikawa, Y., Lkeda, N., Fujioka, N., Watanabe, S.-i., Kuno, K., et al. (1996). Novel insight into molecular mechanism of endotoxin shock: biochemical analysis of LPS receptor signaling in a cell-free system targeting $\mathrm{NF}-\kappa \mathrm{B}$ and regulation of cytokine production/action through $\beta 2$ integrin in vivo. J. Leukoc. Biol. 59 (2), 145-151. doi:10.1002/jlb.59.2.145

Munford, R. S. (2016). Endotoxemia-menace, marker, or mistake?. J. Leukoc. Biol. 100 (4), 687-698. doi:10.1189/jlb.3ru0316-151r

Neff, S. B., Z'graggen, B. R., Neff, T. A., Jamnicki-Abegg, M., Suter, D., Schimmer, R. C., et al. (2006). Inflammatory response of tracheobronchial epithelial cells to endotoxin. Am. J. Physiol. Lung Cell Mol. Physiol. 290 (1), 86-96. doi:10.1152/ ajplung.00391.2004

O'Brien, J. M., and Abraham, E. (2004). Human models of endotoxemia and recombinant human activated protein C. Crit. Care Med. 32, S202-S208. doi:10. 1097/01.ccm.0000126123.34119.98
Ovstebo, R., Brandtzaeg, P., Brusletto, B., Bente Foss Haug, K., Lande, K., Hoiby, E. A., et al. (2005). Use of robotized DNA isolation and real-time PCR to quantify and identify close correlation between levels of Neisseria meningitidis DNA and lipopolysaccharides in plasma and cerebrospinal fluid from patients with systemic meningococcal disease. J. Clin. Microbiol. 43 (1), 532. doi:10.1128/ jcm.43.1.532.2005

Pan, Y., Song, D., Zhou, W., Lu, X., Wang, H., and Li, Z. (2019). Baicalin inhibits $\mathrm{C} 2 \mathrm{C} 12$ myoblast apoptosis and prevents against skeletal muscle injury. Mol. Med. Rep. 20 (1), 709-718. doi:10.3892/mmr.2019.10298

Pan, Y., Chen, D., Lu, Q., Liu, L., Li, X., and Li, Z. (2017). Baicalin prevents the apoptosis of endplate chondrocytes by inhibiting the oxidative stress induced by $\mathrm{H}_{2} \mathrm{O}_{2}$. Mol. Med. Rep. 16 (3), 2985-2991. doi:10.3892/mmr.2017.6904

Pei, H., Zhang, Y., Wu, H., Ren, L., Jia, X., Zhang, Y., et al. (2013). Relationship between iNOS expression and apoptosis in cerebral tissue, and the effect of sini injection in endotoxin shock rats. J. Traditional Chin. Med. 33 (4), 486-491. doi:10.1016/s0254-6272(13)60153-3

Peña, G., Cai, B., Ramos, L., Vida, G., Deitch, E. A., and Ulloa, L. (2011). Cholinergic regulatory lymphocytes re-establish neuromodulation of innate immune responses in sepsis. J. Immunol. 187 (2), 718-725. doi:10.4049/ jimmunol.1100013

Peter, M. E., and Krammer, P. H. (2003). The CD95(APO-1/Fas) DISC and beyond. Cell Death Differ. 10 (1), 26-35. doi:10.1038/sj.cdd.4401186

Piwowar, A. (2014). The advanced oxidation protein products as potential diagnostic and prognostic factor in diseases of the indicated participation of oxidative stress. Postepy. Hig. Med. Dosw. 68, 446-458. doi:10.5604/17322693. 1101545

Reichardt, F., Chassaing, B., Nezami, B. G., Li, G., Tabatabavakili, S., Mwangi, S., et al. (2017). Western diet induces colonic nitrergic myenteric neuropathy and dysmotility in mice via saturated fatty acid- and lipopolysaccharide-induced TLR4 signalling. J. Physiol. 595 (5), 1831-1846. doi:10.1113/jp273269

Rong, L., Li, Z., Leng, X., Li, H., Ma, Y., Chen, Y., et al. (2020). Salidroside induces apoptosis and protective autophagy in human gastric cancer AGS cells through the PI3K/Akt/mTOR pathway. Biomed. Pharmacother. 122, 109726. doi:10. 1016/j.biopha.2019.109726

Shou, X., Wang, B., Zhou, R., Wang, L., Ren, A., Xin, S., et al. (2017). Baicalin suppresses hypoxia-reoxygenation-induced arterial endothelial cell apoptosis via suppressing pkcס/p53 signaling. Med. Sci. Monit. 23, 6057-6063. doi:10. 12659/msm.907989

Simpson, A. J. H., Opal, S. M., Angus, B. J., Prins, J. M., Palardy, J. E., Parejo, N. A., et al. (2000). Differential antibiotic-induced endotoxin release in severe melioidosis. J. Infect. Dis. 181 (3), 1014-1019. doi:10.1086/315306

Stevenson, C. S., Capper, E. A., Roshak, A. K., Marquez, B., Eichman, C., Jackson, J. R., et al. (2002). The identification and characterization of the marine natural product scytonemin as a novel antiproliferative pharmacophore. J. Pharmacol. Exp. Ther. 303 (2), 858-866. doi:10.1124/jpet.102.036350

Sun, M. Y., Ma, D. S., Zhao, S., Wang, L., Ma, C. Y., and Bai, Y. (2018). Salidroside mitigates hypoxia/reoxygenation injury by alleviating endoplasmic reticulum stress-induced apoptosis in H9c2 cardiomyocytes. Mol. Med. Rep. 18 (4), 3760-3768. doi: 10.3892/mmr.2018.9403

Sunil, V. R., Connor, A. J., Lavnikova, N., Gardner, C. R., Laskin, J. D., and Laskin, D. L. (2002). Acute endotoxemia prolongs the survival of rat lung neutrophils in response to 12-O-tetradecanoyl-phorbol 13-acetate. J. Cel. Physiol. 190 (3), 382-389. doi:10.1002/jcp.10074

Suzuki, K., Murakami, T., Kuwahara-Arai, K., Tamura, H., Hiramatsu, K., and Nagaoka, I. (2011). Human anti-microbial cathelicidin peptide LL-37 suppresses the LPS-induced apoptosis of endothelial cells. Int. Immunol. 23 (3), 185-193. doi:10.1093/intimm/dxq471

Thatikonda, S., Pooladanda, V., Sigalapalli, D. K., and Godugu, C. (2020). Piperlongumine regulates epigenetic modulation and alleviates psoriasis-like skin inflammation via inhibition of hyperproliferation and inflammation. Cell Death Dis. 11 (1), 21. doi:10.1038/s41419-019-2212-y

Tian, W., Guo, H.-S., Li, C.-Y., Cao, W., Wang, X.-Y., Mo, D., et al. (2019). PFKFB3 promotes endotoxemia-induced myocardial dysfunction through inflammatory signaling and apoptotic induction. Toxicol. Appl. Pharmacol. 368, 26-36. doi:10.1016/j.taap.2019.02.007

Ulevitch, R. J., and Tobias, P. S. (1995). Receptor-dependent mechanisms of cell stimulation by bacterial endotoxin. Annu. Rev. Immunol. 13, 437-457. doi:10. 1146/annurev.iy.13.040195.002253 
Walzog, B., Jeblonski, F., Zakrzewicz, A., and Gaehtgens, P. (1997). $\beta 2$ integrins (CD11/CD18) promote apoptosis of human neutrophils. FASEB J. 11 (13), 1177-1186. doi:10.1096/fasebj.11.13.9367353

Wang, C.-Z., Zhang, C.-F., Chen, L., Anderson, S., Lu, F., and Yuan, C.-S. (2015). Colon cancer chemopreventive effects of baicalein, an active enteric microbiome metabolite from baicalin. Int. J. Oncol. 47 (5), 1749-1758. doi:10.3892/ijo.2015.3173

Wang, Z., Zhao, S., Song, L., Pu, Y., Tan, N., Liu, X., et al. (2018). Natural cyclopeptide RA-V inhibits the NF-kB signaling pathway by targeting TAK1. Cell Death Dis 9 (7), 715. doi:10.1038/s41419-018-0743-2

Wei, Y. P., Bai, H., Sun, Y. Q., Bao, S., Xi, R., and Liu, L. (2013). Effect of salidroside on apoptosis of bone marrow mesenchymal stem cells induced by ara-C. Zhongguo Shi Yan Xue Ye Xue Za Zhi 21 (6), 1572-1577. doi:10.7534/j.issn. 1009-2137.2013.06.039

Williams, G. T. (1991). Programmed cell death: apoptosis and oncogenesis. Cell 65 (7), 1097-1098. doi:10.1016/0092-8674(91)90002-g

Wu, J., Luo, Y., Jiang, Q., Li, S., Huang, W., Xiang, L., et al. (2019). Coptisine from Coptis chinensis blocks NLRP3 inflammasome activation by inhibiting caspase1. Pharmacol. Res. 147, 104348. doi:10.1016/j.phrs.2019.104348

Wu, X., Zhi, F., Lun, W., Deng, Q., and Zhang, W. (2018a). Baicalin inhibits PDGFBB-induced hepatic stellate cell proliferation, apoptosis, invasion, migration and activation via the miR-3595/ACSL4 axis. Int. J. Mol. Med. 41 (4), 1992-2002. doi:10.3892/ijmm.2018.3427

Wu, X., Zhou, W., Wei, Q., Chen, P., and Li, Y. (2018b). Cytoprotective effects of the medicinal herb Astragalus membranaceus on lipopolysaccharide-exposed cells. Mol. Med. Rep. 18 (5), 4321-4327. doi:10.3892/mmr.2018.9483

Xiong, Y. X., Chen, L., Fan, L., Wang, L. L., Zhou, Y. J., Qin, D. L., et al. (2018). Free total Rhubarb Anthraquinones protect intestinal injury via regulation of the intestinal immune response in a rat model of severe acute pancreatitis. Front. Pharmacol. 9, 75. doi:10.3389/fphar.2018.00075

Yan, R., Xu, H., and Fu, X. (2018). Salidroside protects hypoxia-induced injury by up-regulation of miR-210 in rat neural stem cells. Biomed. Pharmacother. 103, 1490-1497. doi:10.1016/j.biopha.2018.04.184

Yao, J., Cao, X., Zhang, R., Li, Y. X., Xu, Z. L., Zhang, D. G., et al. (2016). Protective Effect of baicalin against experimental colitis via suppression of oxidant stress and apoptosis. Pharmacogn. Mag. 12 (47), 225-234. doi:10.4103/0973-1296. 186342

Yu, C.-P., Shia, C.-S., Lin, H.-J., Hsieh, Y.-W., Lin, S.-P., and Hou, Y.-C. (2016). Analysis of the pharmacokinetics and metabolism of aloe-emodin following intravenous and oral administrations in rats. Biomed. Chromatogr. 30 (10), 1641-1647. doi:10.1002/bmc.3735

Yu, C., Qi, D ., Sun, J. F., Li, P., and Fan, H. Y. (2015). Rhein prevents endotoxininduced acute kidney injury by inhibiting NF-кB activities. Sci. Rep. 5, 11822. doi:10.1038/srep11822

Yu, Y., Liu, H., Yang, D., He, F., Yuan, Y., Guo, J., et al. (2019). Aloe-emodin attenuates myocardial infarction and apoptosis via up-regulating miR-
133 expression. Pharmacol. Res. 146, 104315. doi:10.1016/j.phrs.2019. 104315

Zhang, B., Liu, Y., Zhang, J.-S., Zhang, X.-H., Chen, W.-J., Yin, X.-H., et al. (2015). Cortistatin protects myocardium from endoplasmic reticulum stress induced apoptosis during sepsis. Mol. Cell Endocrinol. 406, 40-48. doi:10.1016/j.mce. 2015.02 .016

Zhang, F., Wang, X., Tong, L., Qiao, H., Li, X., You, L., et al. (2011). Matrine attenuates endotoxin-induced acute liver injury after hepatic ischemia/reperfusion in rats. Surg. Today 41 (8), 1075-1084. doi:10.1007/s00595-010-4423-9

Zhang, X. P., Li, C. Y., Zhang, J., Ruan, Y. F., and Ma, M. L. (2009). Protection of salvia miltiorrhizae to the spleen and thymus of rats with severe acute pancreatitis or obstructive jaundice. Mediators Inflamm. 2009 (2), 186136. doi:10.1155/2009/186136

Zhao, J., Yan, S., Zhu, X., Bai, W., Li, J., and Liang, C. (2020). PTPRO exaggerates inflammation in ulcerative colitis through TLR4/NF- $\mathrm{\kappa B}$ pathway. J. Cell Biochem. 121 (2), 1061-1071. doi:10.1002/jcb.29343

Zheng, W.-x., Cao, X.-l., Wang, F., Wang, J., Ying, T.-z., Xiao, W., et al. (2015). Baicalin inhibiting cerebral ischemia/hypoxia-induced neuronal apoptosis via MRTF-A-mediated transactivity. Eur. J. Pharmacol. 767, 201-210. doi:10.1016/ j.ejphar.2015.10.027

Zheng, Y. J., Yan, M., Lu, L. B., Chang, L. W., Jin, J. B., and Xiao, M. D. (2018). Sophocarpine attenuates LPS-induced liver injury and improves survival of mice through suppressing oxidative stress, inflammation, and apoptosis. Mediators Inflamm. 2018, 5871431. doi:10.1155/2018/5871431

Zhu, J., Wang, X. J., and Li, J. (2019). Pharmacological mechanism and apoptosis effect of baicalein in protecting myocardial ischemia reperfusion injury in rats. Pak. J. Pharm. Sci. 32, 407-412.

Zhu, L., Wei, T., Gao, J., Chang, X., He, H., Luo, F., et al. (2015). The cardioprotective effect of salidroside against myocardial ischemia reperfusion injury in rats by inhibiting apoptosis and inflammation. Apoptosis 20 (11), 1433-1443. doi:10.1007/s10495-015-1174-5

Zhu, Y., Fu, Y., and Lin, H. (2016). Baicalin inhibits renal cell apoptosis and protects against acute kidney injury in pediatric sepsis. Med. Sci. Monit. 22, 5109-5115. doi:10.12659/msm.899061

Conflict of Interest: The authors declare that the research was conducted in the absence of any commercial or financial relationships that could be construed as a potential conflict of interest.

Copyright $\odot 2021$ Liu, Wang, Luo, Zhang, Zhang, Gan, Shen, Zhang and Meng. This is an open-access article distributed under the terms of the Creative Commons Attribution License (CC BY). The use, distribution or reproduction in other forums is permitted, provided the original author(s) and the copyright owner(s) are credited and that the original publication in this journal is cited, in accordance with accepted academic practice. No use, distribution or reproduction is permitted which does not comply with these terms. 